\title{
RAKOUSKÁ STATISTIKA ŠKOLSTVÍ A VZDĚLÁVÁNÍ - OPOMÍJENÝ PRAMEN DĚJIN VZDĚLANOSTI „DLOUHÉHO“ 19. STOLETÍ
}

\author{
PETR KADLEC
}

\section{AUSTRIAN STATISTICS ON SCHOOLING AND EDUCATION: AN OFTEN-NEGLECTED SOURCE FOR THE HISTORY OF EDUCATION IN THE 'LONG' NINETEENTH CENTURY}

This study deals with statistics describing Austrian schools and education in 1828-1915. The potential of this source has so far been used by researchers only most sporadically. The text presents the development of key statistical series, their contents, potential uses, and draws attention to some difficulties which researchers working with school statistics are likely to encounter.

Keywords: statistics - schools - education - 19th century - 20th century - sources

DOI: $10.14712 / 23365730.2021 .18$

\section{Úvod}

Cílem předkládaného textu je poskytnout základní vhled do statistiky rakouského školství a vzdělávání, kterou autor vnímá jako důležitý pramen k dějinám vzdělanosti „dlouhého“ 19. století, oboru, jenž se (nejen) v českých zemích zejména v posledních letech utěšeně rozvíjí. ${ }^{1}$ Představení vývoje a obsahu pramene, jeho možností i limitů by mohlo pomoci badatelům využít více potenciálu, který tento zdroj skýtá pro studium dějin školství a vzdělávání v letech 1828-1915. Ačkoliv disponujeme pro některé prameny kvalitně zpracovanými „,návody“, pro sledované období je podobně zaměřených textů obecně velmi málo. ${ }^{2}$ Uvedené se patrně přičiňuje o pouze minimální využívání řady pramenů

1 K tomu např. Petr Kadlec, On the State of Czech Research in History of Education in the „Long “ 19th Century, Vestnik slavianskikh kul'tur 46, 2017, s. 8-26; TÝŽ, Studium dějin vzdělanosti českých zemi 18.-20. stoletíbilance a perspektivy výzkumu, Acta Universitatis Carolinae - Historia Universitatis Carolinae Pragensis 58/2, 2018, s. 51-60; Miroslav Novotný - Petr Svobodný, Úvodem k dějinám školství a vzdělanosti v českých zemich, in: Miroslav Novotný (ed.), Školství a vzdělanost, Praha 2020, s. 11-15.

2 Srov. např. Petr Kadlec, Prameny k dějinám vzděláni a školstvi (Tištěné programy/výročni zprávy/ středních škol, školské schematismy a středoškolské hlavni katalogy), in: Milan Myška - Aleš Zářický a kol., Prameny k hospodářským a sociálním dějinám novověku 2, Ostrava 2010, s. 252-289; Dietmar HAUBFLEISCH - Christian RITZI, Schulprogramme - zu ihrer Geschichte und ihrer Bedeutung für die Historiographie des Erziehungsund Bildungswesens, in: Irmgard Siebert (Hg.), Bibliothek und Forschung. Die Bedeutung von Sammlungen für die Wissenschaft, Frankfurt am Main 2011, s. 165-205; Veronika KuthanovÁ - Barbora MachovÁ - Eva ŠIPÖczovÁ, Školni kroniky, in: Roman Doušek et al., Archivní prameny v etnologickém výzkumu, I, Brno 2014, 
k dějinám vzdělanosti, rakouskou školskou statistiku přitom nevyjímaje, což je ve výsledku ke škodě věci. ${ }^{3}$

Přestože se pozornost rakouských statistiků koncentrovala zejména na školské instituce, jejich vyučující a studující mládež, neopomíjeli zcela ani předškolní péči ani ústavy, instituce a spolky, jež by bylo možné označit dnes jako vzdělávací, osvětové, kulturní nebo výchovné. Konkrétně se následující text soustředí na pravidelně vydávanou oficiální statistiku, která byla vedena a zveřejňována od konce třetího desetiletí 19. století až téměř do rozpadu habsburské monarchie. Nutno předeslat, že se nejedná o rozbor obsahu a zachycení proměn v čase jediného pramene, resp. statistické řady. Rakouská statistika školství a vzdělávání zahrnovala větší počet př́ruček, které na sebe různou měrou navazovaly, doplňovaly se, př́ípadně se během určitého časového úseku více či méně překrývaly. Vybrána byla díla, která představují podle názoru autora skutečné reprezentanty statistického zpracování stavu a rozvoje rakouských školských i mimoškolských vzdělávacích, osvětových a výchovných institucí. Geografický prostor, k němuž se zprostředkovaná statistická data vztahují, zahrnuje především předlitavskou část habsburské monarchie. Pro období téměř do konce 80 . let 19. století jsou zde však předloženy rovněž cenné údaje o situaci v Zalitavsku, byt' ne kontinuálně a vždy o stejné hloubce. Stranou zájmu studie zůstaly prameny, které sice obsahují užitečná statistická data o oblasti školství a vzdělávání, ale tato jsou omezena pouze na menší jednotky (země, okresy, obce, jednotlivé školské instituce), nebo konkrétní a často jediný sledovaný jev (gramotnost obyvatel, školy určitého oboru či typu). ${ }^{4}$

\section{Vznik a vývoj rakouské statistiky školství a vzdělávání}

Počátky úřredně organizovaného statistického zpracování dat školských a vzdělávacích institucí v Rakousku souvisejí se vznikem oficiální správní statistiky, který lze v habsburské

s. 199-208; Karla VyMĚTALOvÁ, Bibliografie článků klasických filologů ve výročních zprávách středních škol v Čechách, na Moravě a ve Slezsku za léta 1850-1938, Opava 2014 (zejm. s. 14-42).

3 Se svazky rakouské statistiky školství a vzdělávání pracovali badatelé spíše jen ojediněle. Větší měrou je využili např́klad Michail Nikolajevič Kuzmin, Gary B. Cohen, autorská dvojice Bogus - Spyra nebo autor předkládaného textu. Srov. Michail Nikolajevič Kuzmin, Vývoj školství a vzdélání v Československu, Praha 1981; Gary B. Cohen, Education and Middle-Class Society in Imperial Austria 1848-1918, West Lafayette 1996; Marzena Bogus, Nauczyciele szkół ludowych Ślaska Cieszyńskiego w XIX i na poczqtku XX wieku. Uwarunkowania prawne i zawodowe, Czeski Cieszyn - Częstochowa 2013; Marzena Bogus - Janusz SpyrA, Nauczyciele oraz ich stowarzyszenia na tle dyskursu społecznego w modernizujacej się Europie, Toruń 2019; Petr KadLec, Středni školy a jejich studenti. K formování inteligence na severní Moravě a ve Slezsku ve druhé polovině 19. a na počátku 20. století, Ostrava 2013; TÝž, Vzdělání-společnost-hospodářství. Utvárení profesně vzdělávací infrastruktury v Předlitavsku od poloviny 19. století do roku 1914 na př́kladu rakouského Slezska, Červený Kostelec 2020.

4 Příkladem mohou být zemské statistiky školství a vzdělávání (pro Slezsko zveřejňované ve zvláštních kapitolách Statistisches Handbuch für die Selbstverwaltung in Schlesien; o pramenech pro území Čech Dobroslav KREJČí, Školská statistika, in: František Pražák /ed./, Československá škola a výchova. Sborník České pedagogické společnosti v Brně, Brno 1928, s. 27-32), městské adresáře, programy/výroční zprávy středních a vysokých škol, školské schematismy, topografické práce 18. a 19. století, statistika sčítání lidu od roku 1880, statistika gymnázií a reálek otiskovaná od počátku 50. let 19. století jako příloha časopisu Zeitschrift für die österreichischen Gymnasien, statistika zemědělských a lesnických škol i mimoškolních vzdělávacích aktivit v ročenkách ministerstva orby (Berichte über die Thätigkeit des $k$. $k$. Ackerbauministeriums) a v časopise Land- und forstwirthschaftliche Unterrichts-Zeitung nebo statistika průmyslově-živnostenského školství zveřejňovaná pravidelně na stranách časopisu Centralblatt für das gewerbliche Unterrichtswesen in Österreich. 
monarchii klást do konce 20. let 19. století. ${ }^{5} \mathrm{~V}$ závěru roku 1829 byla ve Vídni vydána litografovaná publikace Versuch einer Darstellung der oesterreichischen Monarchie in statistischen Tafeln 1828, připravená zejména pro potřeby nejvyšších vládních úředníků na základě př́kazu císaře Františka I. Johannem svobodným panem Metzburgem (1780-1839) z c. k. Generálního účetního ředitelství. Na tuto práci navázalo v prríštím roce jako její druhý ročník stejně koncipované dílo Darstellung der oesterreichischen Monarchie in statistischen Tafeln 1829. Od třetího ročníku pro rok 1830 vycházela statistika již pod obecně známým názvem Tafeln zur Statistik der oe [ö]sterreichischen Monarchie (dále TZS) až do počátku 70. let 19. století, přičemž poslední ročník obsahuje data pro léta 1860-1865. 6 $T Z S$ představovaly první pravidelně vydávanou statistickou řadu v monarchii, jejíž obsah a forma se postupně zdokonalovaly $\mathrm{v}$ závislosti na zkvalitňování obsazení autorského kolektivu, pokroku v metodě zpracování a rovněž díky recepci zahraničních vzorů. Tento aspekt je nutné zohlednit při sledování zde otiskované statistiky školských, vzdělávacích a výchovných institucí, která byla zveřejňována konkrétně v oddíle Cultur spolu s dalšími dosti nesourodými oblastmi (zdravotnictví, zemědělství, obchod, průmysl, doprava, poštovnictví aj.). Nutno dodat, že ve dvou souhrnných vydáních pro léta 1845-1846 a 1847-1848 se zájemce o oblast školství a vzdělávání dočká pouze dat pro léta 1846, resp. 1847.7 Jiným dílem, jež lze využít při studiu vzdělávacího sektoru první poloviny 19. století je přehledová práce Uebersicht- Tafeln zur Statistik der österreichischen Monarchie, která vyšla v roce 1850 jako zvláštní výtisk 10. a 11. sešitu Statistische Mittheilungen. ${ }^{8}$

Zatímco pro první polovinu 19. století představovala jediný kontinuálně vydávaný statistický výkaz o stavu rakouského školství a vzdělávání řada $T Z S$, pro druhou polovinu téhož století lze využít více př́ruček. Zejména pro období 50 . let 19. století náleží nezastupitelné místo statistice zveřejňované v rámci řady Mittheilungen aus dem Gebiete der Statistik (dále Mittheilungen). ${ }^{9}$ Hned první ročník obsahuje ve svém čtvrtém sešitě cenné pojednání o stavu vyššího a středního školství v monarchii v polovině 19 . století. ${ }^{10}$ Stejný předmět

5 Souhrnně ke konstituování oficiální statistiky, včetně soupisu jednotlivých svazků Jaroslav PoDzımEK, Vývoj čs. statistiky do vzniku státního úr̆adu statistického, Praha 1974; o statistice v širší perspektivě např. Wolfgang GöDERLE, Zensus und Ethnizität. Zur Herstellung von Wissen über soziale Wirklichkeiten im Habsburgerreich zwischen 1848 und 1910, Göttingen 2016 (užitečné zdroje k tématu zde na s. 43, pozn. 1).

6 V rámci TZS je nutné rozlišovat původní řadu zakončenou dvoudílným ročníkem 20-21 pro léta 1847 a 1848 a novou řadu (TZS. Neue Folge) se svazky 1-5 pro období let 1849-1865. Zatímco pro první řadu bylo, s výjimkou dvou zmiňovaných dvoudílných vydání pro dvě léta, typické zpracování pouze jediného roku, nová řada zahrnula ve svých sešitech vždy období několika let.

7 Srov. TZS für die Jahre 1845 und 1846. Achtzehnter und neunzehnter Jahrgang. Zweiter Theil, Wien 1851, Tafel 11-13; TZS für die Jahre 1847 und 1848. Zwanzigster und einundzwanzigster Jahrgang. Zweiter Theil, Wien 1853, Tafel 11-13.

8 Na základě porovnání údajů zveřejněných v rámci řady TZS a dat z Uebersichts- Tafeln zur Statistik lze konstatovat, že druhá pomůcka představuje v podstatě jen stručnější verzi prvé při zachování stejné struktury prezentovaných dat. Na poměrně malém prostoru 15 stran je zde na rozdíl od TZS vyvážená kombinace tabulkové a textové části. Oproti TZS však Uebersichts- Tafeln zur Statistik předkládají až na výjimky (např. univerzity) pouze zemskou statistiku pro jednotlivé části monarchie.

9 Statistická řada Mittheilungen vycházela v letech $1852-1874$ a navázala na svého předchůdce v podobě Mittheilungen über Handel, Gewerbe und Verkehrsmittel, sowie aus dem Statistik überhaupt (1850-1851). Celkem vyšlo v rámci Mittheilungen 20 ročníků, dále členěných na sešity.

10 Mittheilungen. Erster Jahrgang, Heft 4: Die höheren Lehranstalten und Mittelschulen der österreichischen Monarchie im Studienjahre 1851, Wien 1852. 
zájmu měly i další dvě školské statistiky otištěné v rámci Mittheilungen: souhrnné statistiky pro školní léta 1851-1857 a 1851-1870. ${ }^{11}$

Po dvě desetiletí zveřejňoval ve zvláštních kapitolách základní data o školství a vzdělávání Statistisches Jahrbuch, komplexní statistická publikace pro 60. a 70. léta 19. století, uvedená v život v roce 1863 zrízenou c. k. Ústřední statistickou komisí $(K$. $k$. Statistiche Central-Commission). ${ }^{12}$ Poprvé vyšla ročenka v roce 1864 a přinesla údaje o vyučovacích ústavech všech stupňu a typů pro rok (1862) 1863 a výchovných institucích a spolcích vědecko-průmyslově-uměleckého zaměření pro rok 1862. Poslední Statistisches Jahrbuch z roku 1884 zaznamenal situaci na poli školství a vzdělávání ve školním roce 1880/1881. Vydávání statistické ročenky skončilo na základě rozhodnutí jejího vydavatele ze 7. října 1882, přičemž za její nástupce byly označeny publikace Österreichisches Statistisches Handbuch für die im Reichsrathe vertretenen Königreiche und Länder (dále ÖSH) a Österreichische Statistik (dále $O ̈ S$ ). ${ }^{13}$ Obě uvedené príručky pak skutečně představovaly od poč́tku 80 . let 19 . století $\mathrm{v}$ pravidelných ročních intervalech veřejnosti data o stavu školských a výchovných zařízení až do první světové války. Zatímco závěrečný ročník ÖSH popisuje ještě situaci v kalendářním roce $1915,{ }^{14}$ podrobnější ÖS (Neue Folge) dovedla svá statistická šetření pouze do školního roku 1913/1914.15

Nepřekvapí patrně, že se vzhledem ke státně politickým souvislostem a změnám v uspořádání monarchie po tzv. rakousko-uherském vyrovnání z roku 1867, proměnil rovněž způsob statistického šetření a jeho zveřejňování. Obě části monarchie disponovaly od té doby vlastními statistickými úřady, které zpracovávaly a vydávaly statistiku pro země př́slušející do jejich působnosti. Zvlášt' tedy vycházela od roku 1867 statistika pro země předlitavské (zastoupené na Říšské radě) a země zalitavské. Pouze výjimečně byla zveřejněna data v rozsahu celé monarchie. Vedle již zmiňovaného Statistisches Jahrbuch pro rok 1867 obsahuje celostátní údaje a cenné srovnání stavu školství a vzdělanosti období cirka

11 Mittheilungen. Siebenter Jahrgang. Statistik der Lehranstalten des österreichischen Kaiserstaates für die Studienjahre 1851-1857, Wien 1858 (Heft I: Abtheilung I: Universitäten und andere höhere Lehranstalten; Heft IV, Abtheilung II: Gymnasien und andere Mittelschulen); Mittheilungen. Achtzehnter Jahrgang, Heft 3: Die Zunahme der Verbrechen verglichen mit der Vermehrung der Bevölkerung in Österreich unter der Enns, Österreich ob der Enns und Salzburg von 1857 bis 1869. Die Hoch- und Mittelschulen der im Reichsrathe vertretenen Königreiche und Länder von 1851 bis 1870. Mit einer Karte, Wien 1871.

12 V textu bude pro zjednodušení dále používán zkrácený název př́ručky - Statistisches Jahrbuch. Tato statistická ročenka vycházela až do svazku pro rok 1866 pod názvem Statistisches Jahrbuch der oesterreichischen Monarchie. Pro následující rok zněl titul statistiky Statistisches Jahrbuch der oesterreichisch-ungarischen Monarchie für das Jahr 1867 a název dalších svazků s daty pro léta 1868-1881 Statistisches Jahrbuch für das Jahr 1868 (1869, 1870 atp.).

13 Statistisches Jahrbuch für das Jahr 1881, Wien 1884, s. III.

14 V letech 1883-1918 vyšlo celkem 35 ročníků ÖSH. Až do 34. ročníku pro rok 1915 vycházel ÖSH kontinuálně vždy po jednom svazku pro určitý rok, pouze poslední ročník obsáhl v jednom svazku léta 1916-1917. Na rozdíl od jiných tematických oblastí však byla statistika školských zařízení dovedena pouze do kalendářního roku 1915.

15 V rámci statistické řady $O ̈ S$ vyšlo v letech 1882-1912 celkem 93 svazků, na které navázalo 18 svazků nové rady (ÖS Neue Folge) z let 1912-1919. Komplexní statistika vzdělávacích a výchovných institucí vycházela s přibližně dvou- až tříletým zpožděním. Posledním svazkem, v němž je pojednáno o vyučovacích ústavech v předlitavské části habsburské monarchie, je 17. svazek ÖS Neue Folge z roku 1919 (Heft 3) s daty pro školní rok 1913/1914. 
od poloviny 70. do poloviny 80 . let 19. století v obou částech monarchie například Statistisches Handbuch - Statisztikai kézikönyv z roku $1888 .{ }^{16}$

Specifickou a statistiky obzvláště sledovanou oblast školství představovaly školy primární (Volksschulen, národní školy), zahrnující v daném období školy obecné (Allgemeine Volksschulen) a měštanské (Bürgerschulen). Základní informace o stavu primárního školství v letech 1828-1915 poskytují ve formě sumářů pro jednotlivé země monarchie (po roce 1867 Předlitavska) výše uvedené statistiky TZS, Statistisches Jahrbuch, ÖSH, ÖS a ÖS Neue Folge. Podstatně podrobnější přehled o primárních školách, jejích učitelích a žactvu ovšem skýtají teprve samostatně vydané statistické práce, nebot' sestupovaly až na úroveň jednotlivých školních okresů. Impulsem pro sestavení první z nich pro rok 1865 (vydána 1870) byl 3. mezinárodní statistický kongres ve Vídni (1857) a realizace této statistiky byla posvěcena ministerským výnosem z 11. 2. 1865 č. 7828. Výrazné legislativní změny v primárním školství v závěru 60 . let, podřízení $\mathrm{c}$. $\mathrm{k}$. Ústřední statistické komise ministerstvu kultu a vyučování v roce 1870 a důležitost této vzdělávací sféry vedly $\mathrm{k}$ opakovaným nařízením $\mathrm{k}$ provedení samostatného statistického šetření primárních škol rovněž pro léta $1871,1875,1880,1890$ a $1900 .{ }^{17}$ Zatímco první čtyři statistiky pro léta $1865-1880$ představují samostatně vydané práce, statistiky pro léta 1890 a 1900 vyšly jako zvláštní svazky v rámci řady $O \ddot{S} .^{18}$

\section{Obsah a charakteristika pramene}

\section{TZS}

Proměny statistiky školství a vzdělávání otiskované v rámci $T Z S$ souvisely úzce $\mathrm{s}$ vývojem této nejdéle zpracovávané rakouské statistické řady. Během více než čtyřiceti let (1829-1871) svého vydávání doznala $T Z S$ poměrně značných změn. $Z$ hlediska vnější stránky byl krokem vpřed ročník 14 (statistika pro rok 1841), který znamenal konec litograficky rozmnožovaných tabulek a zároveň přechod na v tisku tehdy využívané novogotické

16 Statistisches Jahrbuch der oesterreichisch-ungarischen Monarchie für das Jahr 1867, Wien 1869; Statistisches Handbuch. Statisztikai kézikönyv. Statistisches Handbuch der österreichisch-ungarischen Monarchie. Neue Folge, Wien 1888. Ze speciálních statistických příruček pro zalitavskou část habsburské monarchie, kde lze dohledat údaje o rozvoji tamního vzdělávacího sektoru po roce 1867, jmenujme alespoň Magyar Statisztikai Évkönyv z let 1872-1918.

17 Původně avizovaná statistická šetření elementárního školství pro školní léta 1884/1885, 1894/1895 a 1904/1905 byla nakonec odvolána. Zveřejnění se dočkaly pro tato léta jen údaje zemských školních rad podle okresů, otištěné nakonec v rámci ÖS, resp. v jejích tematických svazcích Statistik der Unterrichts-Anstalten (Band XVI, Heft 2, Wien 1887; Band LI, Heft 1, Wien 1898; Band LXXIX, Heft 3, Wien 1908).

18 Detailconscription der Volksschulen in den im Reichsrathe vertretenen Königreichen und Ländern nach dem Stande vom Ende des Jahres 1865, Wien 1870; Statistik der öffentlichen und privat Volksschulen in den im Reichsrathe vertretenen Königreichen und Ländern. Nach den von den Bezirks-Schulbehörden für das Schuljahr 1870-1871 vorgelegten Erhebungen, Wien 1873; Statistik der öffentlichen und privat Volksschulen...f für das Schuljahr 1875, Wien 1876; Statistik der öffentlichen und privat Volksschulen... nach dem Stande des Schuljahres 1880. Nebst einer summarischen Übersicht sämmtlicher Lehranstalten, Wien 1882; Oesterreichische Statistik. Band XXXV, Heft 1: Statistik der allgemeinen Volksschulen und Bürgerschulen in den im Reichsrathe vertretenen Königreichen und Ländern. Auf Grund der statistischen Aufnahme vom 30. April 1890, Wien 1892; Österreichische Statistik. Band LXII, Heft 2: Statistik der allgemeinen Volksschulen und Bürgerschulen... Auf Grund der statistischen Aufnahme vom 15. Mai 1900, Wien 1903. 
lomené písmo švabach. Ve všech oblastech zahrnutých do TZS se odrazil postup institucionalizace a profesionalizace vedení rakouské statistiky (1840 vznik c. k. Ředitelství správní statistiky, 1863 c. k. Ústřední statistické komise), precizace metodiky a její zpř́stupnění široké veřejnosti (úplně až pro ročníky z poloviny 40 . let). ${ }^{19} \mathrm{Zprvu}$ jen ojedinělý textový doprovod, nejčastěji ve formě krátkých poznámek a komentářu o maximálně několika větách, postupně nabýval na významu a rozšiříl se až na několik stran vyhrazených pro určitý oddíl. Také poslední svazky nové řady $T Z S$ však zůstaly věrny názvu statistiky a dominantní místo $\mathrm{v}$ nich i nadále náleželo statistickým datům v tabulkách.

Statistika školských a výchovně-vzdělávacích ústavů a organizací náležela mezi tradiční složky otiskované v rámci $T Z S$ v obsahově rozmanitém oddíle o kultuře (Cultur). $\mathrm{S}$ výjimkou posledního svazku nové řady TZS byla zveřejňována $\mathrm{v}$ tabulkách rozvržených do tř́ kapitol: Lehranstalten, Erziehungsanstalten a Bildungsanstalten. ${ }^{20}$ Svazek pro léta 1860-1865 obsahuje pouze kapitolu o vyučovacích ústavech, která se soustředila s výjimkou vojenských výchovných ústavů pouze na statistiku školských institucí. Během let se zvětšoval rozsah uvedených kapitol, především pak oddílu o vyučovacích ústavech. Zatímco v prvních ročnících obsahovala statistika výchovně-vzdělávacích institucí a organizací pouze okolo jedenácti stran a ještě ve 13 . ročníku pro rok 1840 čítala šestnáct stran, souhrnný svazek pro ročníky 20-21 (pro léta 1847-1848; u sledované statistiky ale jen s daty pro rok 1847) věnoval témuž oddílu již 51 stran. Více prostoru náleželo téže statistice až ve svazcích nové řady TZS: v prvním pro léta 1849-1851 necelých 100 stran a v závěrečném pátém svazku pro léta 1860-1865 dokonce 162 stran. ${ }^{21}$ Celkově lze říci, že statistice školství a vzdělávání náleželo důležité místo v rámci $T Z S$, i když na prostoru jí vyměřeném se to projevilo plně až v závěrečném období vydávání této statistické řady.

Obsahová náplň a struktura statistiky školství a vzdělávání v rámci $T Z S$ zůstávaly v hlavních rysech stejné. Postupně se však v souvislosti s rozvojem vzdělávací soustavy rozšiřoval počet do statistiky zahrnutých ústavů. Přibývalo rovněž sledovaných kritérií a rubrik, rostl tedy počet zveřejňovaných statistických dat a tím i informační základna, kterou $T Z S$ poskytovala o oblasti školství a vzdělávání.

Kapitolu o vyučovacích ústavech lze tematicky rozdělit do dvou hlavních celků: statistiku škol poskytujících vyšší než elementární vzdělání (od odborných škol přes stř̌edoškolské ústavy, rozmanitá vyšší učiliště až k univerzitám) a statistiku primárního školství. V první části byly poskytovány až do 40 . let 19 . století skutečně jen základní informace o školách, jejich vyučujících a studentech (celkové počty, náklad na školy, počty stipendistů apod.). Pouze u vyšších kategorií vzdělávacích ústavů sestupovali rakouští statistikové až na úroveň konkrétních škol, přičemž ale například u univerzit nebyla zprvu zjišt'ována data zvlášt'

19 Podle Jaroslava Podzimka nejsou údaje z prvních patnácti ročníků (tedy včetně ročníku pro rok 1842) zcela spolehlivé, nebot' se na jejich tvorbě podíleli pracovníci řady vládních a zemských úřadů bez potřebné statistické kvalifikace. J. PoDzimek, Vývoj, s. 93.

20 Zde i dále v textu bude používán pro dnešního čtenáře bližší a jasnější výraz „kapitola“ pro soustavu tabulek k určitému tématu, která byla ve svazcích TZS označována pouze jako Tafel. Zároveň budou pro uvedené německé výrazy pro zjednodušení používány následující české ekvivalenty: vyučovací, výchovné resp. vzdělávací ústavy.

21 První svazek nové řady TZS se sice soustředil především na rok 1851, ale zároveň obsahuje i cenné základní informace o stavu školských a mimoškolských výchovně-vzdělávacích ústavů v letech 1849-1850. Srov. TZS. Neue Folge. Band I: Das Jahr 1851 mit übersichtlicher Einbeziehung der Jahre 1849 und 1850 darstellend, Zweiter Theil, Wien 1856 (Tafel 14-16). 
pro jednotlivé fakulty. U gymnázií a jiných škol zařaditelných dnes mezi středoškolské ústavy byla až do 40. let 19. století předložena statistika celozemská, u gymnázií byla v jednotlivých zemích dále diferencována maximálně do určitých podskupin škol (ráádová, piaristická, akademická apod.). Mnohem podrobnější přehled o stavu vyšších škol nabízejí svazky TZS od roku 1851. Teprve údaje vztahující se ke školnímu roku 1850/1851 umožňují poznat lépe skladbu vyučujících a především jejich studentstva, u kterého byl nyní pro většinu vyšších škol zjišt’ován status, původ (domácí, cizinci), náboženské vyznání, národnost (v 60. letech 19. století mateřský jazyk). Část věnovaná primárnímu školství obsahovala od počátku celozemská data, specifikovaná dále na úroveň jednotlivých farních (školních) okresů s vnitřním rozlišením na školy katolické a nekatolické, respektive školy hlavní, triviální, dívčí, opakovací a v případě nekatolických i židovské. ${ }^{22}$ Obvykle jsou zde čtenářům předloženy vedle počtu škol informace o jejich vyučovacím jazyce a základní údaje o počtu a skladbě vyučujících, žactvu (včetně rozlišení na chlapce a dívky), počtu školou povinných dětí a nákladu na školy. Také podkapitola o primárním školství obsáhla postupně stále větší objem statistických dat. Poslední svazek přinesl díky tomu například podstatně podrobnější vhled do skladby učitelských sborů (včetně ženského osazenstva s rozlišením podle jednotlivých druhů škol a kvalifikace aj.), škol podle organizace a délky vyučování, náboženského vyznání žáků, stavu školních budov a způsobu jejich vydržování. ${ }^{23}$

Předmětem zájmu kapitoly o výchovných ústavech, zvlášt' vedené v TZS pro léta 1828 až 1859 , byly instituce, u nichž byl důraz položen vedle vzdělání na výchovu jedince ve shodě s účelem a orientací př́slušného ústavu. Tato statistika zahrnovala širokou škálu rozličných institucí, u nichž lze někdy nalézt společné pojítko jen velmi těžko. Zveřejňována zde byla např́klad data o Tereziánské rytiřské akademii ve Vídni, konviktech a seminářích, teologických učilištích, klášterních ústavech, institucích poskytujících vojenské vzdělání (Vojenská akademie ve Vídni-Novém Městě /Theresianische Militär-Akademie zu Wiener Neustadt, Inženýrská akademie /Ingenieur Akademie-zu Wien, později $k$. $k$. Technische Militärakademie/, kadetky ad.), institutech pro slepé a hluchoněmé, ústavech pro dcery důstojníků nebo o Dámském spolku v Praze. Před polovinou 19. století prribyly mezi sledované výchovné ústavy rovněž dětské opatrovny. Utř́iěna byla tato velmi diferencovaná skupina ústavů nejprve na veřejné a soukromé, dále podle jednotlivých zemí a pohlaví (mužské, ženské, smíšené). Statistické šetření sestupovalo až na úroveň jednotlivých ústavů, pouze pokud jich v dané zemi existoval větší počet, jsou předložena o dané skupině souhrnná data celozemská. Sledován byl vedle počtu vyučujících a služebných, chovanců a chovanek, rovněž počet stipendistů, nadanců a náklad potřebný na provoz. Důležitou součástí kapitoly představuje přiložený sumář o celkovém počtu výchovných ústavů a jeho chovanců, v němž je načrtnuto základní možné třídění této nesourodé skupiny institucí. $Z$ počátku uplatňované členění na výchovné ústavy pro mužskou mládež (zde dále na všeobecně-vzdělávací, duchovní, vojenské), ženskou mládež a smíšené ústavy se později dále prohlubovalo. Ve 40. letech se již např́íklad u každé z uvedených tř́i hlavních kategorií rozlišovaly ústavy

22 Naznačené třídění doznalo v průběhu vývoje TZS určitých změn a dalších specifikací. V posledním svazku pro rok 1865 byl např́iklad zjišstován počet škol hlavních pro chlapce (s rozlišením s/bez připojených reálek), dívky, obě pohlaví, rozšířených triviálních škol (farních hlavních škol) pro chlapce, dívky či obojí pohlaví, počet triviálních škol (pro chlapce, dívky, chlapce a dívky) a tzv. nouzových škol (Nothschulen). Srov. TZS. Neue Folge. Band V: Die Jahre 1860 bis 1865 umfassend, Wien 1871, s. 82-83 (Volksschulen im Jahre 1865).

23 Tamtéž, s. 82-89. 
všeobecně-vzdělávací, sirotčince, soukromé vzdělávací instituty), u smíšených také instituty pro hluchoněmé a slepé. ${ }^{24}$

Podobně jako kapitola o výchovných ústavech, tak i oddíl věnovaný vzdělávacím ústavům byl pravidelně sledován ve svazcích $T Z S$ až do konce 50. let 19. století, tzn. s výjimkou posledního svazku pro léta 1860-1865. Určitou shodu lze nalézt i po obsahové stránce: rovněž statistika výchovných ústavů předkládala údaje o poměrně nesourodé skupině institucí, organizací a spolků. Zahrnovala učené společnosti, vzdělávací a jinak zaměřené spolky (výtvarné, hudební ad.), akademie, společnosti pro podporu umění, průmyslu, zemědělství nebo vlastivědy. Ze všech lze uvést například vídeňskou Akademii výtvarných umění a zdejší Zemědělskou společnost, pražskou Společnost Vlasteneckého muzea a Královskou českou společnost nauk, jihlavský Hudební spolek a brněnskou Moravskoslezskou společnost pro podporu zemědělství, prrírody a vlastivědu při místním Františkově muzeu. Statistika sestupovala $\mathrm{v}$ rámci jednotlivých částí monarchie až na úroveň konkrétních ústavů a spolků, u nichž sledovala počet a skladbu členů (vedoucí, vyučující, řádní, mimořádní, korespondenční), počet chovanců (pokud je uvedené společnosti měly), náklad na provoz, prémie, stipendia a nadace. Kapitolu uzavíral tabulkový sumář shrnující data ke vzdělávacím ústavưm, jenž shrnoval uvedené údaje pro určité skupiny vzdělávacích ústavů. Členění do skupin se přitom postupně dále vyvíjelo. ${ }^{25}$

Na rozdíl od jiných sledovaných oblastí neobsahuje druhý ročník řady TZS pro rok 1829 rekapitulaci statistických údajů pro vzdělávací a výchovné instituce od roku 1819. Shrnutí pro celou dekádu přináší, avšak pouze v části věnované národnímu školství a pro období let 1831-1840, teprve 13. ročník pro rok 1840. Přestože je TZS dovedena až do roku 1865, tzn. ukončena ještě před rakousko-uherským vyrovnáním, neobsahuje vždy část o školství a vzdělávání data pro celé území monarchie. Až do roku 1850 scházejí např́íklad ve statistice primárního školství údaje pro Uhry (v roce 1828 i pro Sedmihradsko), podobně je tomu u vzdělávacích ústavů až do 40. let 19. století v př́padě Uher a Sedmihradska. Statistika výchovných ústavů obsáhla zpravidla celý prostor habsburské monarchie, ovšem i u ní schází např́klad pro rok 1840 údaje z Uher. Souhrnné počty pro zalitavskou část monarchie scházejí obecně u sumářù v kapitole věnované vyučovacím ústavům, dále u statistiky pro léta 1849-1850 nebo ve statistice uměleckých a hudebních institutů v roce 1865.

\section{Mittheilungen}

Na rozdíl od $T Z S$ představovaly publikace z řady Mittheilungen díla zaměřená pouze na určité téma nebo oblast. Tabulkové výkazy se zde plynule prolínaly s textovými komentáři, přičemž samotnému textu náleželo podstatně důležitější místo než u TZS. Z hlediska školství a vzdělávání se pozornost tvůrců Mittheilungen soustřed'ovala oproti široce

24 Srov. TZS für die Jahre 1847 und 1848. Zwanzigster und einundzwanzigster Jahrgang. Zweiter Theil, Wien 1853, Tafel 12 (Erziehungs- Anstalten im Jahre 1847).

$25 \mathrm{Z}$ počátku obsahovalo celkové shrnutí pět skupin vzdělávacích ústavů: učené společnosti, vědecké spolky a muzea; akademie výtvarných umění; zemědělské společnosti; umělecké spolky. TZS pro rok 1840 obsáhly navíc i skupinu spolků průmyslových. Ve 40. letech 19. století se tř̌idění v sumáři ustálilo na následujících sedmi sledovaných skupinách institucí: ústavy pro všeobecné vědecké vzdělání; pro speciální vědecké vzdělání; všeobecné umělecké vzdělání; vzdělání hudební; podporu zemědělství; podporu průmyslu a pro podporu vlastivědné práce. Srov. TZS pro léta 1831, 1840, 1843 a 1849-1851. 
koncipovaným TZS pouze na vyučovací ústavy poskytující vyšší než elementární vzdělání. ${ }^{26}$ Pro výrazně odlišné uspořádání dat $\mathrm{v}$ jednotlivých svazcích bude užitečné, když budou stručnou formou představeny všechny tři statistiky pro léta 1851, 1851-1857 a 1851-1870.

Impulsem pro vydání statistiky středních a vyšších vyučovacích ústavů ve školním roce $1851(1850 / 1851)$ byly na počátku 50. let 19. století hluboké změny v oblasti vyučování uváděné v habsburské monarchii do školské praxe od roku 1849. Protože správa vyučovacích ústavů byla rozdělena do více institucí, obrátilo se c. k. Ředitelství správní statistiky podléhající tehdy ministerstvu obchodu na ministerstva orby a hornictví, kultu a vyučování a války s požadavkem, aby požádaly jim podřízené vedoucí úřady vy̌šśích škol a ředitelství středních škol o statistický výkaz jejich učitelů, studentů, školského zařízení apod. ${ }^{27}$ Tímto způsobem sesbíraná a utr̂́iděná data pak dala vzniknout do té doby nejpodrobnějšímu a nejrozsáhlejšímu (208 s.) statistickému výkazu o stavu vyšších škol (zde ve smyslu škol poskytujících vyšší než elementární vzdělání). Konkrétně zahrnula statistika následující vyučovací ústavy:

1) vyšší školy - univerzity; technické instituty; báňské, zemědělské a lesnické ústavy, jejichž studenti nabyli určitého vzdělání již na středních školách; chirurgická učiliště; školy pro porodní báby (ty existovaly bud' samostatně, nebo ve spojení s univerzitami, př́ípadně $\mathrm{s}$ chirurgickými učilišti);

2) střední školy - gymnázia, reálky, hornické školy a rolnické školy.

Důležité bylo, že se tvưrcům statistiky podařilo shromáždit data o vyučovacích ústavech $\mathrm{z}$ celé monarchie. Publikaci lze rozdělit na dvě hlavní části: oddíly věnované postupně situaci v jednotlivých zemích monarchie a závěrečné celkové shrnutí. Kapitolu o každé zemi uvozuje stručný text s výčtem místních vyšších a středních škol v roce 1851, po němž následují komentované statistické údaje v tabulkách, vyhotovených pro jednotlivé vyučovací ústavy (od gymnázií přes reálky, odborné školy až po univerzity). Statistické šetření sestupuje na úroveň jednotlivých škol a poskytuje o nich základní informace (počet škol a tříd, počet a skladba vyučujících /rozlišení podle kvalifikace/ i studentů /národnost, vyznání/, učebních sbírkách, školném, zřizovatelích apod.). Nejvíce údajů je předloženo o nejvýznamnějších vyučovacích ústavech - univerzitách. U nich jsou mimo výše uvedené informace, rozvedené až na úroveň fakult, připojeny také statistika univerzitních zkoušek a informace o přednáškách, sbírkách a univerzitní knihovně. Přehledné shrnutí v závěru publikace pak přináší souhrnná celozemská data o hlavních sledovaných kritériích ke gymnáziím, celostátní k odborným školám, technickým učilištím, právnickým akademiím a univerzitám (zde i na úrovni fakult). Jako dodatek je připojena na posledních několika stranách také stručná charakteristika jednotlivých vojenských vzdělávacích a výchovných ústavů (umístění, počet vyučujících, počet i skladba chovanců a studentů /vyznání, národnost/, vyučované předměty). ${ }^{28}$

Statistika stejných vyučovacích ústavů pro léta 1851-1857 byla rozdělena do dvou svazků a otištěna v prvním a druhém sešitě 7. ročníku Mittheilungen. Autorem byl v obou př́ipadech Gustav Adolph Schimmer (1828-1902), revident c. k. Ředitelství správní statistiky.

\footnotetext{
26 Ojedinělým počinem otištěným v rámci Mittheilungen bylo zveřejnění statistiky národního školství v zalitavské části monarchie. Mittheilungen. Jahrgang 2, Heft 3: Die Volksschulen in Ungarn, Croatien, Slavonien und in der Vojvodschaft Serbien (mit den Temeser Banate) im Jahre 1851, Wien 1853.

27 Mittheilungen. Erster Jahrgang, s. 1.

28 Tamtéž, s. 202-208.
} 
Předmětem prvního svazku (152 s.) byly různé typy vyšších škol (univerzity, teologická a chirurgická učiliště, technické, právnické a obchodní akademie, školy pro porodní báby), druhý svazek o 106 stranách obsahoval údaje ke gymnáziím a jiným typům středních škol (reálky, obchodní a plavební školy). Záběr statistiky byl opět celostátní, přičemž statistické šetření sestupovalo na úroveň jednotlivých zemí a dále i konkrétních škol. Zásadní odlišsnost vůči statistice pro rok 1851 existovala v uspořádání obou svazků, nebot' byly rozvrženy do kapitol podle sledovaného typu školy (univerzity, teologická učiliště... gymnázia apod.), k němuž předkládaly vždy veškeré dostupné statistické údaje. Každou kapitolu uvozoval krátký text o jejich účelu, historii, současné organizaci výuky, učebním plánu, vývoji a nákladu. ${ }^{29}$ Po úvodní pasáži pak následovala komentovaná statistická data v tabulkách s rozborem hlavních vývojových tendencí. Statistika zahrnula celkem sedmileté období, ovšem výkazy pro léta 1851-1856 podávají opravdu jen základní informaci o počtu škol, vyučujících a studentů. U univerzit, jimž byla věnována zvýšená pozornost, například navíc ještě o promocích, disputacích nebo výsledku zkoušek na učitelská místa. Podrobnější údaje poskytuje statistika pouze pro rok 1857 (školní rok 1856/1857), u něhož lze proniknout mj. do skladby učitelstva, struktury studentů (náboženské vyznání, národnost), plateb poplatků spojených se studiem, stipendií, materiálního vybavení vyučovacích ústavů, zkoušek, u vyšších škol i přednášek a vyučovaných předmětů.

Souhrnná statistika středních a vysokých škol pro léta 1851-1870, jejímž autorem byl konceptní adjunkt c. k. Ředitelství správní statistiky Wilhelm Leitgeb, se od výše uvedených svazků výrazně liší. $\mathrm{V}$ prvé řadě zahrnovala pouze území předlitavské části monarchie, a to jak v retrospektivě pro léta před i po roce 1867. Pozornost se přitom soustředila na univerzity, technické vysoké školy a jim podobné ústavy (Lvov, Krakov, Terst) a střední školy (gymnázia, reálky, reálná gymnázia). ${ }^{30}$ Ambicióznímu úkolu vytčenému v úvodu díla, a sice podat statistický obraz o zmiňovaných vysokých a středních školách v období od poloviny 19. století, bylo vyměřeno poměrně málo prostoru. Nevelký počet stran (jen 107) způsobil, že publikace představuje vskutku jen základní vývojové tendence o rozvoji vyučovacích ústavů při zachycení stavu v pěti základních časových bodech $(1851,1855,1860,1865,1870)$. Rozvržena je do šesti kapitol věnovaných postupně vývoji počtu a skladby škol, učitelských sil (kvalifikace, u středních škol s rozlišením světských a duchovních učitelů), studentů (náboženství, národnost /podle kritéria mateřské řeči/), jejich materiálnímu zázemí (stav knihoven, kabinetů, laboratoří, učebních pomůcek a sbírek) a nákladu potřebnému na vydržování jednotlivých typů škol (včetně zdrojů vynakládaných finančních prostředků). Důležité je, že tabulky doprovázejí bohaté komentáře $\mathrm{s}$ vysvětlením hlavních trendů. Statistická data jsou předložena většinou v celopředlitavských, popř. v zemských souhrnech. Zatímco u univerzit a technik sestoupila statistika u některých sledovaných kritérií (napřs. složení učitelských sborů v roce 1870) až na úroveň jednotlivých škol, v príípadě gymnázií a reálek se tak stalo až v závěrečném sumáři s údaji

29 V kapitole věnované gymnáziím informuje úvodní text vedle historie a uspořádání gymnaziálního školství také o disciplinárním řádu, maturitách, prázdninách, učitelích, vyučovacích předmětech, přijímací taxe a školném. Srov. Mittheilungen. Siebenter Jahrgang, Heft 4, s. 1-19.

30 Zatímco ústavy ve Lvově a Krakově se v době vydání díla reorganizovaly, na Akademii pro obchod a lodní plavbu v Terstu nahlížel tvůrce statistiky jako na speciální technické učiliště. Vedle uvedených typů škol si na jediném místě všiml rovněž ústavů ke vzdělání učitelů a učitelek, konkrétně jejich počtu v jednotlivých zemích Předlitavska. Mittheilungen, Achtzehnter Jahrgang, s. 30, 36. 
o počtu učitelů a studentů v letech 1851-1870. Nedílnou a cennou součást publikace představuje mapka s rozmístěním středních a vysokých předlitavských škol v roce 1870, na níž jsou vedle zmiňovaných ústavů zaznačeny rovněž školské instituce vzdělávající aspiranty učitelské profese v primárním školství.

\section{Statistisches Jahrbuch a ÖSH}

Cenný zdroj informací o oblasti školství a vzdělávání, zvlášt’ pro období od poloviny 60. let do počátku 80. let 19. století, představuje statistika zveřejňovaná ve svazcích Statistisches Jahrbuch. Zprvu přibližně sedmdesátistránková díla se vlivem rozvoje vzdělávacího sektoru a postupnou precizací některých ve statistice sledovaných kritérií rozrostla v průběhu 70. let na práce s počtem stran vysoce převyšujícím stovku, přičemž v závěrečném svazku již atakovala dokonce hranici dvou set stran. Od počátku nebyla této statistice vyhraněna jediná kapitola, nýbrž více oddílů, které byly většinou rozvrženy do větších celků. Nutno dodat, že změny v utrrídění statistiky do kapitol a podkapitol kopírovaly celkové proměny príručky Statistisches Jahrbuch v průběhu dvaceti let vydávání této ročenky. ${ }^{31}$ Zatímco ve svazcích pro léta 1863-1870 byl zvláštní prostor vyhrazen rovněž výchovným ústavům, soustředili se tvůrci statistiky pro léta 1871-1881 na ústavy vyučovací. S tím souviselo mimo jiné přesunutí výkazu o dětských opatrovnách, původní součásti statistiky výchovných ústavů a samostatné kapitoly ve svazcích pro léta 1866-1871, do kapitoly o zdravotnictví a dobročinných ústavech v publikaci pro rok $1872 .{ }^{32}$

Data zveřejněná v rámci Statistisches Jahrbuch výhradně ve formě tabulek zahrnovala až do svazku pro rok 1867, byt' obvykle ne vždy u všech sledovaných rubrik, celé území habsburské monarchie, po roce 1867 pak jen údaje pro země její předlitavské části. Statistika poskytovala obraz o stavu celé vzdělávací soustavy, napříč různými stupni a typy škol. S výjimkou nejnižší kategorie škol (zemské přehledy) přitom sestupovala na úroveň jednotlivých vzdělávacích ústavů. U škol, na nichž se nabývalo vyšší než elementární vzdělání, bylo možné zjistit vždy přinejmenším jejich počet, celkový stav učitelstva a studentstva, někdy také s rozlišením na chlapce a dívky. Uvedené se týkalo především odborně profilovaných a speciálních ústavů. Podstatně větši pozornost byla věnována od počátku gymnáziím, reálkám a především technickým vysokým školám (až na úroveň jejich jednotlivých oddělení) a univerzitám (vedle jednotlivých fakult rozlišována situace v zimním a letním semestru). Právě u nich bylo již od počátku možné proniknout hlouběji do struktur učitelských sborů a studentů (status, náboženské vyznání, mateřský jazyk, u univerzit a technik později ještě domovská země), statistiky zkoušek (u gymnázií a reálek také směřování absolventů po maturitě) nebo do problematiky studijních poplatků. Postupně se rovněž

31 Pro ilustraci: první svazek Statistisches Jahrbuch pro rok 1863 členil statistiku školství a vzdělávání do dvou oddílů (Vyučovací ústavy v roce 1863; Výchovné ústavy, vědecké, průmyslové a umělecké spolky v roce 1862); svazek pro rok 1872 jí věnoval již pět kapitol, ročník 1879 patnáct a závěrečný svazek pro 1881 shrnul dostupná statistická data ve čtyřech kapitolách (Vysoké školy a jiná vyšší odborná učiliště v roce 1880/1881; Střední a odborné školy v roce 1880/1881; Národní školy v roce 1880/1881; Souhrnná rekapitulace všech vyučovacích ústavů v roce 1880/1881), přičemž výklad o předškolní péči o děti v roce 1881 byl veden jako zvláštní podkapitola v části publikace o zdravotnictví a dobročinných ústavech.

32 Cenný je záznam o předškolních ústavech pro děti, jesličkách a dětských školkách, který byl připojen ke statistice dětských opatroven. Zatímco u jesliček se tak stalo již ve Statistisches Jahrbuch pro rok 1866, u školek až ve svazku pro rok 1877 . 
u ostatních vyšších škol zvyšoval počet sledovaných kritérií, a čtenář tak získává čím dál přesnější prredstavu i o zdejších vyučujících a studentech. Statistika primárního školství přinášela vedle celkového počtu školských zařízení jejich třídění do jednotlivých typů (později také tříd, popř. podle toho, zda disponovala právem veřejnosti či nikoliv), cenné informace o vyučovacím jazyce škol, stavu a skladbě učitelského sboru (kvalifikace, později zvláštní pozornost věnována ženám), žactvu a vůbec dětech ve školou povinném věku, v závěru vydávání Statistisches Jahrbuch též o organizaci vyučování, vybavení škol a celkovém stavu školních budov. Zprvu zveřejňovaná statistika výchovných ústavů poskytovala sice skromné, přesto cenné základní údaje o jejich počtu, výchovném personálu a množství chovanců, přičemž i zde se postupně rozšiřovalo spektrum předkládaných informací (u veřejných ústavů zachycena např́klad i skladba chovanců podle náboženství a stipendia).

O poznání stručnější statistickou pomůckou než Statistisches Jahrbuch, kde lze nalézt souhrnné údaje ke školským a vzdělávacím ústavům, představoval jeho nástupce $O ̈ S H$. V letech 1883-1918 zde vycházely vždy na přibližně čtyřiceti stranách tabulkové přehledy s nejzákladnějšími informacemi o situaci v předlitavském vzdělávacím sektoru v období školních let 1880/1881-1914/1915, u nejvýznamnějších ústavů (univerzity, techniky, vyšší odborná učiliště, gymnázia, reálky a učitelské ústavy) s retrospektivou dovedenou až do 70. let 19. století. Na rozdíl od svého předchůdce byla tato statistika předložena vždy v rámci jediné a stále stejně nazvané kapitoly o vyučování (Unterrichtswesen), jež byla dále vnitřně členěna. Tvưrci $O ̈ S H$ se zaměřili především na školy poskytující vyšší než elementární vzdělání, avšak pravidelně zde zařazovali také stručnou statistiku primárního školství a základní souhrnná data k výchovným ústavům, ačkoliv bez bližšího určení typu nebo dokonce konkrétní školy. ${ }^{33}$

Zatímco statistika univerzit, technik a dalších vyšších učilišt' sestupovala v ÖSH s výjimkou části o teologických ústavech - až na úroveň jednotlivých škol, byly údaje o všech typech středních škol (gymnázia, reálky, reálná gymnázia), nižších odborných školách a o primárním školství předloženy pouze ve formě zemských přehledů. Nejpodrobnější informace o školách, jejich učitelském sboru a studentstvu poskytovala statistika ÖSH o univerzitách, technikách (včetně Vysoké školy zemědělské ve Vídni /Hochschule für Bodenkultur/), gymnáziích a reálkách. ${ }^{34} \mathrm{U}$ ostatních vyšších učilišst byla větší pozornost věnována pouze skladbě vyučujících. Ze skupiny odborně profilovaných odborných škol lze vyzdvihnout podrobnější informace o ústavech určených ke vzdělání učitelů a učitelek pro primární školství a složení žactva průmyslově-živnostenských škol. Zemské přehledy o primárních školách si všímaly vedle počtu škol jejich zřizovatele, vyučovacího jazyka, vyučujících a žáků, ovšem detailnější pohled poskytují teprve později vydané ročníky. Celkově lze konstatovat, že se statistika školství a vzdělávání otiskovaná v rámci ÖSH proměnila během více než třicet let jen poměrně málo a dílčí změny vedly spíše $\mathrm{k}$ jejímu zpřehlednění a rozšíření počtu sledovaných rubrik u škol podrobených statistickému šetření.

33 V pozdějších letech se součástí přehledů o primárním školství staly také instituty pro hluchoněmé, výchovné ústavy (školy) pro slepé, ústavy pro slabomyslné děti (pomocné školy), školky a dětské opatrovny. Uvedená statistika se ale až do konce vydávání řady ÖSH neudržela. Srov. svazky ÖSH pro léta 1907, 1915 a $1916-1917$.

34 U zmiňovaných škol se v případě učitelů jednalo o statistiku jejich skladby z hlediska kvalifikace. Studenti byli tříděni podle statusu, národnosti, náboženského vyznání, v případě univerzit a technik též podle domovské země. Vedle toho byla pozornost věnována rovněž zkouškám realizovaných na školách a problematice školného a stipendií. 
Svazky vydávané v rámci řady $O ̈ S$ představovaly skutečný vrchol rakouské statistiky školství a vzdělávání z hlediska zpracování, komplexnosti i šiřre předkládaných dat. Pro školní léta 1881/1882 až 1913/1914 poskytují poměrně ucelený statistický obraz rozvoje předlitavské vzdělávací soustavy, konkrétně pak zejména té její části, jež sloužila ke zprostředkování vyššího než jen elementárního vzdělání. Zcela stranou však nezůstaly ani školství primární nebo rozmanité výchovné ústavy. Při tvorbě sledované statistiky vzdělávacích institucí se promítly pozitivně zkušenosti nabyté v předchozích desetiletích na poli statistického šetření a zpracovávání dat, dovršení profesionalizace vedení rakouské statistiky, podřízení c. k. Ústřední statistické komise ministerstvu kultu a vyučování i etablování systému školských úřadů a obecně zdokonalení vedení školské agendy.

Každý z celkem 32 svazků školské statistiky otištěných v řadě ÖS obsahoval vždy dvě hlavní části: I) úvodní text, II) statistické tabulky.

\section{ad I)}

Vstupní textová část o rozsahu kolísajícím zpravidla mezi dvaceti až čtyřiceti stranami byla dále rozdělena do podkapitol podle typů škol sledovaných dále v tabulkovém oddíle. V zásadě obsahovala čtyři hlavní podkapitoly věnované postupně vysokému školství, středním školám (gymnázia, reálky, reálná gymnázia, později i dívčí gymnázia), odbornému školství a primárním školám. Jedním z úkolů výkladu, doprovázeného zároveň tabulkami, bylo představit vývojové trendy hlavních typů vzdělávacích ústavů v předcházejícím obvykle zhruba desetiletém - období. Vůbec první zveřejněná statistika pro školní rok 1881/1882 proto obsahuje cennou retrospektivu vývoje stavu předlitavského školství od počátku 70. let 19. století. S výjimkou vysokoškolských ústavů bylo uplatňováno především měřítko celopředlitavské, popř. zemské. Text měl charakter zprvu spíše komentáře přiložených tabulek, teprve postupně se mu dostalo celkově většího prostoru a spěl více k pokusům o stručný analytický rozbor. ${ }^{36}$ Množství a hloubka podaných informací nebyly u všech sledovaných typů škol stejné. Od počátku náležela větší pozornost univerzitám a gymnáziím, teprve postupně přibývalo údajů i pro další školy (zejm. ostatní vysoké školy, reálky, průmyslově-živnostenské školy). Sledoval se např́ílad vývoj počtu škol, počtu a složení učitelských sborů (podle kritéria kvalifikace učitelů) a studentů (náboženství, mateřský jazyk, později též státní př́slušnost), výsledek zkoušek na vysokých školách, úspěšnost u maturit na školách středních, problematika poplatků spojených se studiem, vyučovací jazyk škol, vybavenost školskými institucemi atd. Vítanou součástí textové části se staly ve svazku pro školní rok 1889/1890 výjimečně připojené vzory statistických

35 Následující text je věnován pravidelně otiskované komplexní statistice školských a vzdělávacích ústavů, která vycházela v rámci $O ̈ S$ (Neue Folge) pravidelně pro každý školní rok počínaje rokem 1881/1882 ve zvláštních sešitech jako Statistik der Unterrichts-Anstalten in den im Reichsrathe vertretenen Königreichen und Ländern. O svazcích ÖS věnovaných výhradně primárnímu školství je pojednáno v této studii zvlášt'.

36 Srov. např. ÖS. Band III, Heft 2: Statistik... für das Jahr 1881/1882, Wien 1884, s. I-XXII; ÖS. Band XXVIII, Heft 4: Statistik... für das Jahr 1889/1890, Wien 1892, s. I-XL; ÖS. Band LXVIII, Heft 3: Statistik... für das Jahr 1899/1900, Wien 1903, s. I-XXXIV; ÖS. Neue Folge. Band 7, Hef 3: Statistik... für das Jahr 1909/1910, Wien 1913 , s. $1^{*}-28^{*}$. 
formulářů, jak je předepisoval výnos ministerstva kultu a vyučování z 18. června 1883 pro obchodní a průmyslově-živnostenské školy. ${ }^{37}$

\section{ad II)}

Tabulkové statistické přehledy představovaly těžiště svazků řady ÖS. Právě tato část publikací statistiky školství a vzdělávání se během více než třiceti let nesmírně rozrostla. Pro ilustraci uved'me, že zatímco první svazek pro školní rok 1881/1882 čítal pouze 83 stran tabulek, osmačtyřicátý svazek pro rok 1890/1900 již 250 a statistika pro rok 1912/1913 dokonce 344 stran. Zásadním způsobem se o to přičinil překotný rozvoj odborného školství v závěru 19. století, především průmyslově-živnostenských škol, respektive prostor věnovaný mu rakouskými statistiky, což jen potvrzovalo rostoucí důležitost přisuzovanou tomuto vzdělávacímu segmentu předlitavskou státní správou. ${ }^{38}$ Rostoucí počet předlitavských průmyslově-živnostenských a ostatních druhů odborných škol způsobil, spolu s rozšířením sledovaných rubrik, že před první světovou válkou zahrnovala jejich statistika přibližně $2 / 3$ náplně svazků ÖS. Obsah tabulkové části lze rozdělit na dva hlavní celky: statistická data k jednotlivým vzdělávacím ústavům (IIa) a stručnou závěrečnou rekapitulaci se zemskými přehledy pro všechny do statistiky zahrnuté typy a stupně škol (IIb).

\section{IIa)}

Tato část byla rozdělena do řady dílčích oddílů (podkapitol) v závislosti na sledovaném segmentu vzdělávací soustavy, popř. některém jeho aspektu. V přehledně uspořádaných tabulkách představovala výsledek provedeného statistického šetření. Pořadí jednotlivých oddílů bylo vcelku ustálené a vycházelo vždy z úvodní textové části. Nejprve byla předložena data pro univerzity, dále pro techniky, Vysokou školu zemědělskou ve Vídni a další odborně profilované instituce vysokoškolského charakteru (báňské akademie, obchodní akademie /tyto ale později přesunuty k ostatním obchodním školám/, vysoké umělecké školy, od počátku 20. století též zvěrolékařské vysoké školy, Exportní akademie, Konzulární akademie), za nimiž následovaly údaje pro nejvyšší stupeň teologických učilišt', střední školy (gymnázia, reálky, reálně-gymnazijní kombinace; později i dívčí gymnázia), odborné školy (učitelské ústavy, obchodní učiliště, průmyslově-živnostenské školy, zemědělské a lesnické školy, školy uměleckého zaměření, speciální odborně vzdělávací instituce; uvnitř této skupiny se uplatňovala též vnitřní diferenciace podle specializace a pohlaví vzdělávané mládeže), vzdělávací ústavy bez práva veřejnosti, výchovné ústavy nejrůznějšího druhu a nakonec primární školy.

Hlavní pozornost rakouských statistiků byla upřena tradičně na univerzity, ale za nimi př́liš nezaostávaly ani další vysoké školy, jimž se dostalo ve svazcích ÖS též většího prostoru a časem se jejich statistické výkazy vyrovnaly v podstatě univerzitám spektrem předkládaných informací. Poměrně velké množství dat poskytovala statistika o středních školách (jejich vymezení viz výše), naopak teprve postupně se zvyšoval počet kritérií zjišt’ovaných u některých odborných škol (učitelské ústavy, obchodní a průmyslově-živnostenské školy) a v př́padě primárního školství. Zatímco statistika vysokých, středních a odborných škol sestupovala v rámci zemí až na úroveň jednotlivých ústavů, popř. dokonce jejich

37 ÖS. Band XXVIII, Heft 4: Statistik... für das Jahr 1889/1890, Wien 1892, s. XXXV-XL.

38 Podrobněji k tomu P. KadLec, Vzdělání, s. 149nn. 
částí (fakulty, oddělení), záznamy o primárním školství byly předloženy pouze ve formě celozemských přehledů a údaje o výchovných ústavech či školách bez práva veřejnosti se omezovaly jen na to nejpodstatnější (název a umístění, počet vyučujících a žáků/chovanců). Množství dat zveřejněných ve svazcích $O ̈ S$ se zvlášt' u některých typů školských institucí v průběhu let výrazně rozširiovalo a celkově proměňovalo. Detailní rozbor všech provedených změn a prezentace zjišt'ovaných dat by vydaly na samostatnou studii. Proto poskytne následující část textu vskutku jen ilustrativní přehled o obsahu a hlavní proměně statistiky školských a vzdělávacích institucí otiskované v rámci řady $O ̈ S$.

Podrobné informace získá čtenář $O ̈ S$ na stranách věnovaným vysokému školství, především pak univerzitám. U nich byla od počátku sledována zvlášt' situace $\mathrm{v}$ obou semestrech, přičemž stejný postup se uplatňoval pouze u technik a vídeňské Vysoké školy zemědělské. Statistika univerzit obsahuje, při rozlišení až na úroveň fakult, vedle počtu přednášek např. rozbor složení učitelského sboru (podle kvalifikace) a posluchačů (status, rodná země /později státní př́ślušnost/, mateřský jazyk, náboženské vyznání), problematiky poplatků spojených se studiem (počty částečně či zcela osvobozených, stipendisté, obnos stipendií), zkoušek a zkušebních komisí pro místa středoškolských vyučujících. Ve svazcích z počátku 20. století je zvláštní prostor vymezen rovněž studujícím dívkám. Sledoval se jejich počet $\mathrm{v}$ rámci celkového posluchačstva univerzit, fakult a také mezi studenty farmacie. Podobné údaje, i když ne tak detailní ve všech směrech, lze excerpovat ze statistiky rovněž pro zbývající vysoké školy. Méně je možné dozvědět se o teologických učilištích, u nichž nelze podrobněji proniknout do skladby jejich učitelského personálu a ve statistikách prezentovaná skladba studentů obsahuje pouze data o mateřském jazyce a ve stručné podobě i o výsledcích pořádaných zkoušek. Později se navíc statistika těchto škol přesunula na samotný závěr svazků $O ̈ S$ mezi jiné neprríliš sledované ústavy a ještě více se zestručnila.

Mezi vzdělávací ústavy, jimž byla od počátku věnována patřičná pozornost, náležely střední školy. Stejná kritéria přitom byla sledována u všech typů tehdejších stř̌edoškolských ústavů: gymnázií, reálek, reálně-gymnazijních kombinací a v posledních letech také dívčích gymnázií. U středních škol, utř́děných vždy podle zemí a abecedně podle jejich lokalit, je možné zjistit jejich zřizovatele, vyučovací jazyk, počet tříd, počet a složení učitelských sborů a studentů (status, mateřský jazyk, náboženské vyznání, počty studentů v jednotlivých ročnících), proniknout do problematiky školného a stipendií (počty osvobozených od poplatků, stipendisté), výsledkủ maturitní zkoušek a dalšího směřování studenti̊. ${ }^{39} \mathrm{~V}$ českých zemích byly nejprve v Čechách, posléze i na Moravě, rozlišeny střední školy do skupin podle vyučovacího jazyka, což velmi usnadňuje porovnání stavu školství českého s německým. V závěru sledovaného období přibyly rubriky o státní př́islušnosti studentů a věkové skladbě osazenstva závěrečného ročníku středních škol.

Velmi diferencovanou a na významu stále nabývající část $O ̈ S$ představoval oddíl statistiky odborného školství s daty o velmi různorodé skupině škol (učitelské ústavy, školy

39 U maturit sledovala statistika počty přihlášených a vyzkoušených (s rozlišením na studenty príslušné školy a externisty), úspěšnost (počty úspěšných absolventů, osob poslaných k opakovací zkoušce a reprobovaných), výsledky opakovacích zkoušek, další směřování absolventů (u gymnázií rozlišena tradičně studia teologická, právnická a státovědná, lékařská, filozofická a technická, studenti nerozhodnutí nebo rozhodnutí pro jinou profesní oblast; u reálek rozlišováni absolventi, kteří byli rozhodnuti pro technická studia nebo zůstali v době sběru dat nerozhodnuti). 
obchodní, průmyslově-živnostenské, zemědělské, lesnické, horní nebo plavební, zvěrolékařská učiliště, školy pro porodní báby, ženské pracovní školy, speciální instituty pro hluchoněmé nebo slepé, školy jazykové, umělecké aj.). Nejpodrobnější byla zprvu statistika ústavů ke vzdělání učitelů a učitelek (sledován vyučovací jazyk, skladba vyučujících i chovanců /mateřský jazyk, náboženství/, úspěšnost u maturit a rozlišení absolventů podle aprobace) a průmyslově-živnostenských škol (typ školy, rok založení, vyznání a mateřský jazyk studentů). U ostatních odborných škol uváděla statistika pouze lokalitu, rok založení, celkový počet tříd, vyučujících a studentů. Do první světové války se u učitelských ústavů a průmyslově-živnostenských (a posléze také obchodních) škol zvýšil počet sledovaných kritérií. Přibyla např́klad podrobná specifikace aprobace absolventů učitelských ústavů, u průmyslově-živnostenských škol rozčlenění podle oborů a stupňủ, vyučovací jazyk, stipendia, školné, skladba učitelů, státní príslušnost studentů atd. O něco méně informací lze získat na počátku 20. století o zemědělských a lesnických školách (zrízovatel, vyučovací jazyk, počet ročníků, počet škol spojených s internátem, stav učitelů a studentů /děti hospodár̆ů mezi nimi/, stipendisté, obnos stipendií), o ostatních odborných učilištích různého druhu poskytovaly statistiky nadále pouze základní údaje (místo, počet vyučujících a studentů).

Přestože se zájem rakouských statistiků v př́padě svazků o vyučovacích ústavech soustředil především na instituce poskytující vyšší než elementární vzdělání, nezůstalo zcela stranou ani primární (národní) školství. Na rozdíl od vyšších vzdělávacích ústavů předkládala statistika těchto škol po celou dobu pouze data ve formě zemských přehledů, přičemž trrídila školské instituce do dvou hlavních skupin na veřejné a soukromé. Dalším třídícím hlediskem bylo členění na školy obecné a měšt’anské. V prvních svazcích umožňuje statistika poznat vyučovací jazyk škol a nahlédnout rámcově do jejich učitelských sborů (učitelé tříděni podle kvalifikace a pohlaví), organizace vyučování (celodenní, půldenní, kombinace obojího), stavu školních budov a zařízení škol (odpovídající x neodpovídající), žactva (chlapci x dívky) a vůbec dětí ve školou povinném věku (i těch navštěvujících jiné než národní školy a vyučovaných doma) atd. Posléze se rozššrílo spektrum předkládaných rubrik také na vyučování v jiné zemské řeči a mnohem větší důraz byl položen na vnitřní vybavení školních areálů (knihovny, zahrady nebo zemědělská cvičná pole, školní lékař, kuchyň, školní koupelna, počet vyučovacích místností, využití budov škol), organizaci vyučování (propojení s kurzy průmyslovými, či zemědělskými, u měštanských škol s pokračovacími kurzy pro dívky, popr. jednoletými učebními kurzy). Pozornost však směřovala i mimo primární školy, prričemž se zjišt'oval např́iklad počet výchovných ústavů, opatroven a polepšoven pro zanedbané děti (včetně počtu tříd, učitelů, chlapců a dívek), školek, počty hřišs' pro hry mládeže (Jugendspiele), dětských ohříváren, polévkových ústavů nebo vánočních nadílek. Větší prostor byl věnován také školní docházce dětí ve školou povinném věku (rozložení do veřejných a soukromých obecných a měštanských škol, doplněné o rozlišení škol s právem či bez práva veřejnosti; počet dětí zproštěných docházky kvůli návštěvě středních a odborných škol; počet dětí vyučovaných doma, neschopných výuky ze zdravotních důvodů a těch, které zůstaly bez vyučování).

\section{IIb)}

Závěrečná rekapitulace přinášela vždy celkové shrnutí základních dat. Na zemské úrovni představila počty škol všech stupňů a typů, jejich učitelů a žáků (studentů) podrobených 
statistickému šetření. Údaje pro jednotlivé skupiny škol byly utř́iěny do čtyř hlavních, dále členěných celků: vyšší (vysoké) školy; veřejné stř̌ední školy; speciální veřejné a soukromé školy a výchovné ústavy; veřejné měšt’anské a obecné školy.

\section{Statistiky primárního školství}

Vydávání samostatných svazků statistiky pro nejnižší stupeň vzdělávací soustavy v poslední třetině 19. století odráželo rostoucí důležitost, která byla tomuto segmentu vzdělávání přisuzována. Rovněž předtím sice existovala statistika nejnižší kategorie škol v podobě tzv. diecézních výkazů, tyto však byly zhotovovány v době vrchního církevního dozoru nad školami. Problematickými byly v minulosti, vedle charakteru a množství sledovaných údajů, někdy faktická správnost poskytovaných údajů a zejména nemožnost jejich náležité verifikace. Pro statistiku primárního školství mělo zásadní význam, aby správa a vrchní dozor nad touto částí vzdělávací soustavy podléhaly v plné míře školským úřadům, což nastalo až po vydání zákonu o postavení školy a církve z 25 . května 1868 (Ř. z. č. 48). Neméně důležitá však byla realizace reformy národního školství na přelomu 60. a 70. let 19. století, jež znamenala zásadní reorganizaci jeho správy (mj. zaveden tř́stupňový systém školních rad) a uspořádání škol, změny v povinné školní docházce, vzdělání učitelů atd. Pro zachycení školní docházky je nutné zmínit i pokrok metodiky sčíání lidu, nebot’ teprve od roku 1869 bylo možné zjistit přesný počet dětí ve školou povinném věku.

Vzhledem k době vydávání samostatných statistik primárního školství nepřekvapí rozsah jimi zahrnutého teritoria, jenž pokrýval pouze předlitavskou část habsburské monarchie. Zcela zásadní význam mělo, že na rozdíl od nesamostatných statistik těchto škol nepředkládaly jen celozemská data, nýbrž poskytovaly cenné údaje o nejnižším školství na úrovni školních okresů. Nebylo by smysluplné, abychom zde podrobně analyzovali veškeré vydané př́ručky. Pro ilustraci byly proto vybrány publikace zachycující stav v letech 1871 , 1880, 1890 a rovněž v roce 1900 (školní rok 1870-1871 atp.), v němž se jednak konečně naplno uplatnily výše naznačené změny a aspekty vývoje primárního školství, jednak zahrnují tyto svazky rozhodující část období vydávání statistiky v samostatných publikacích.

Podobně jako u dřive zmiňovaných školských statistik, prodělala rovněž statistika primárních škol ve sledovaném období poměrně značný vývoj. Vedle proměny kvalitativní, jež bude přiblížena dále $\mathrm{v}$ textu, doznala také výrazných změn z hlediska kvantitativního. Spolu s rozšiřováním počtu a specifikací zjišt'ovaných rubrik přibývalo rapidně stránkového rozsahu. Zatímco statistika pro školní rok 1870/1871 obsahovala necelých 130 stran, svazek pro rok 1880 již 511 stran a statistiky pro léta 1890 a 1900 cirka 400, resp. 450 stran.

Zpracování statistických dat naráželo na začátku vydávání statistiky na poměrně značné obtíže. Problémy vyvěraly jednak z minima zkušeností s podobnými pracemi a množství podkladového materiálu, jednak - a to zřejmě zejména - z přivykání na novou organizaci primárního školství. Zpracovatel statistiky pro školní rok 1870/1871 Gustav Adolf Schimmer uvedl $\mathrm{v}$ této souvislosti jako jeden $\mathrm{z}$ důvodů průtahů při její tvorbě přetížení okresních školních inspektorů, které způsobilo prodlužování termínů pro dodání potřebných materiálů. Na konkrétních př́íkladech ilustruje dotyčný také omluvy jednotlivých zemských školních úřadů, proč nedodali požadované informace c. k. Ústřední statistické komisi v předepsaném termínu. Schimmer zároveň upozornil čtenáře, že předkládaná statistika nemůže nabídnout ke všem částem zcela přesné výsledky, nebot' pro dokončení a předložení k tisku 
byly využity rovněž diecézní výkazy pro rok 1868 , doplněné pouze o nová data. ${ }^{40}$ Postupně se však systém získávání a zpracování dat přece jen ustálil a počáteční těžkosti již tvůrci dalších svazků v takovém rozsahu neprožívali. Konání statistiky primárních škol bylo vždy s předstihem vyhlášeno výnosy ministerstva kultu a vyučování, přičemž byly vydány patřičné formuláře a stanoven harmonogram práce. $V$ zásadě lze rozlišit formuláře dvojího druhu: pro vedoucí konkrétních škol (zvlášt' vyhotoveny formuláře pro školy veřejné a soukromé) a pro okresní školní inspektory, které obsahovaly souhrnná data pro př́islušný okres. $\mathrm{K}$ vyplnění formulářu byly vydány přesné instrukce. S nimi měl představitele škol seznamovat právě okresní školní inspektor, jemuž náleželo v celém procesu statistického šetření zásadní místo. Inspektor byl povinen v průběhu školního roku, kdy se konalo dané šetření, vysvětlit učitelům při školních inspekcích, konferencích a jiných příležitostech prrípadné nejasnosti. Od okresních školních inspektorů směřovaly veškeré formuláře (souhrnné i ty z jednotlivých škol) na zemské školní úřady, kde byla přezkoušena jejich úplnost a formální správnost, $\mathrm{v}$ př́padě nutnosti vydán i podnět $\mathrm{k}$ doplnění. Ověřené formuláře pak putovaly na c. k. Ústřední statistickou komisi, která zodpovídala za přezkoušení dat, sestavení statistických přehledů a vydání př́íslušné statistiky.

Statistiky primárního školství obsahovaly zpravidla dvě hlavní části: úvodní textovou (autoři svazku pro školní rok 1879/1880 na ni ovšem rezignovali) a tabulkovou se statistickými výkazy. Nepravidelně byla ke statistikám přičleněna mapová př́loha. Ke svazku pro školní rok 1870/1871 byly připojeny např́íklad tři cenné mapky (znázorňující vztah dětí ve školou povinném věku /chlapci, dívky, celkem/ a žactva škol v zemích Předlitavska podle školních okresů), pro rok 1900 mapka jedna (vztah veřejných škol k obyvatelstvu zemí Předlitavska podle školních okresů). Nepř́liš rozsáhlý úvodní oddíl, který plnil z počátku spíše funkci stručného komentáře hlavních údajů předložených v tabulkové části, se postupně rozrostl na téměř sto stran. Vedle rekapitulace historie statistiky primárního školství a jejich hlavních výsledků od roku 1828 př̀dstavoval organizaci statistiky (včetně použivaných formulářù) a přinášel analýzu stěžejních výsledků. Tabulková část publikací o primárním školství sestávala $\mathrm{v}$ zásadě ze tř́ hlavních celků: statistiky veřejných škol, údajů o soukromých ústavech a shrnutí přinášejícího porovnání základních dat pro oba druhy nejnižší kategorie školských zařízení. Zatímco statistika veřejných i soukromých škol byla dovedena u jednotlivých zemí Předlitavska až na úroveň školních okresů, sumáře předkládaly data pouze ve formě celozemských přehledů.

Nejpodrobnější bylo tradičně statistické šetření o veřejných školách, které zabíralo vždy většinu celkového rozsahu př́slušného svazku. Již ve školním roce 1870/1871 sledovali statistikové vedle celkového počtu škol (s rozlišením na obecné a měšt’anské) jejich členění podle pohlaví, počtu ročníků nebo vyučovacího jazyka. Všímali si rovněž organizace výuky (celoroční-celodenní, celoroční-půldenní), stavu a složení učitelského personálu (kritériem kvalifikace a délka výkonu profese; zvlášt' předkládány informace o ženách-učitelkách), př́ijmů pedagogů, počtu a skladby žactva (mateřský jazyk, náboženství, věkové skupiny /6-12, 12-14, nad 14 let/), forem plnění školní docházky (děti vyučované doma, v soukromých ústavech, na středních školách, bez vyučování) i školních budov a jejich zařízení (budovy vlastní x v nájmu; stav školních budov a učebních prostředků). V př́ípadě

40 Statistik der öffentlichen und privat Volksschulen... für das Schuljahr 1870-1871 vorgelegten Erhebungen, Wien 1873, s. III-IV. 
soukromých škol bylo statistické šetření obecně méně podrobné. Některé rubriky zde, často z logických důvodů, scházejí (školní docházka, služební věk a př́ímy učitelů aj.), jiné jsou naopak typické pouze pro ně (zrrizovatel, disponování právem veřejnosti, do konce 19. století také problematika školného).

Později vydané svazky statistiky primárních škol přinesly určité inovace, které směřovaly většinou $\mathrm{k}$ precizaci dosavadních rubrik, př́padně $\mathrm{k}$ zařazení některých nových kritérií. Statistika veřejných škol pro školní rok 1879/1880 např́klad obsahovala nově zjišt’ování počtu vyučovacích týdnů na školách. Statistickému šetření byly v uvedeném roce rovněž podrobeny nejen věk a vyznání učitelů a učitelek, ale i rozšíření výuky o některé předměty (ženské ruční práce, zemědělství, ovocnářství, hedvábnictví, včelařství). Podrobněji se stejná statistika věnovala školním budovám (sledovány byly např́ílad ventilace, topení, disponování tělocvičnou, zahradou, školkou), knihovnám škol (včetně počtu svazků jejich knih) a opakovacímu vyučování. Pro území Čech je jistě užitečné rozlišení českých a německých školních okresů. Výraznou změnou vůči předchozím svazkům představovalo v roce 1890 zjišt'ování jazykových schopností žáků (Sprachkenntnisse) místo původně sledované mateřské řeči. ${ }^{41}$ Bližší specifikace se dočkal stav školního zařízení a knihoven (rozlišeny knihovny žákovské a učitelské, použivané nářadí a sportoviště př̌i tělesné výchově). Pozornost se také zaměřila na vyučování v druhém zemském jazyce, výuku cizí řeči (francouzština, angličtina, italština, ruština, hebrejština), ústavy a kurzy připojené $\mathrm{k}$ veřejným školám (školky; dětské opatrovny; kurzy zemědělské a průmyslové; všeobecné učební kurzy pro dívky /vždy s počtem škol a žáků-žákyň). Naproti tomu statistika soukromých škol podrobný rozbor složení učitelského sboru, školního zařízení a organizace výuky postrádala. Nad rámec roku 1890 byla do statistiky primárních škol pro rok 1900 zahrnuta např́íklad data o počtu školních dílen, laboratoří pro výuku fyziky a chemie, školném a dětech různým způsobem od jeho platby osvobozených, stipendistech, poměru mužských vyučujících $\mathrm{k}$ vojenské službě, počtu dětí nesvobodných učitelů a učitelek, školách s výukou hry na housle (klavír), kategorizaci učitelů podle platových skupin, expoziturách a exkurendo stanicích škol. U soukromých ústavů byly $\mathrm{v}$ tomto roce nově zařazeny údaje o připojených dětských opatrovnách a školkách, pokračovacích vzdělávacích kurzech pro dívky či o žactvu osvobozenému od platby školného.

\section{Možnosti, limity a komplikace spojené s využitím statistických příruček pro dějiny vzdělanosti}

Rakouská statistika školství a vzdělávání představuje bezesporu velmi cenný a hodnotný zdroj informací nejen o školských institucích a výchovných ústavech, ale i o předškolní péči a výchovně-vzdělávacích spolcích a nejrůznějších organizacích. Významným pramenem je proto pro studium dějin školství, výchovy, vzdělávání a celkově pro bádání na poli kulturních a sociálních dějin 19. a počátku 20. století. Přestože byla statistika ve druhé

41 Autoři příslušného svazku statistiky to zdůvodnili snahou o poskytnutí podstatně bohatšího a přesnějšího vhledu do jazykových poměrů mládeže škol veřejných i soukromých. Zvlášt' u chlapců a dívek bylo zjišt'ováno, na jaké úrovni znají př́islušný zemský jazyk (zda ovládají pouze jeden a jaký, popř. různé kombinace dvou jazyků nebo jestli mohou vykázat větší znalost jednoho z jazyků uvedených v príslušné kombinaci). Srov. ÖS. Band XXXV, Heft 1: Statistik der allgemeinen Volksschulen und Bürgerschulen... Wien 1892, s. LXX-LXXV. 
polovině 19. století rozložena do více statistických příruček, předkládá jako celek komplexní a - s výjimkou prvních ročníků $T Z S$ a nejstarších svazků statistiky primárních škol také spolehlivé údaje o vývoji výchovně-vzdělávacích institucí, jejich vybavení, učitelském a výchovném personálu, studentech, žácích a chovancích. Nutno dodat, že informace předkládané o jednotlivých stupních a typech škol nejsou vždy stejně podrobné a obsahově komplexní. Navíc až v průběhu let, zřetelně zejména od poslední čtvrtiny 19. století, se statistické šetření postupně precizovalo a přibývalo rubrik nejen u nejvýznamnějších a nejvíce sledovaných institucí (vysoké a střední školy, veřejné primární školy), ale i u statistikami dřive vcelku opomíjených ústavů (odborné školy, předškolní péče o děti). U klíčových parametrů vývoje vzdělávací infrastruktury ovšem statistika zachycuje období od zahájení jejího vydávání v závěru 20. let 19. století až do počátku první světové války. Podstatně podrobnější informaci přitom předkládá pro dobu od poloviny 19. století, kdy je nadto možné - a pro vytvoření celistvého obrazu také užitečné - kombinovat více př́ruček. Celkově vzato, umožňují práce rakouských statistiků studium hlavních vývojových tendencí, trendů a vybraných jevů předlitavské školské a částečně i mimoškolní soustavy v poměrně dlouhém časovém horizontu necelých devadesáti let. Zejména při studiu vzdělávacích a výchovných institucí $\mathrm{v}$ předlitavské části habsburské monarchie bude badateli statistika vděčným pomocníkem s tím, že pro první polovinu 19. století zahrnuje zpravidla do svých přehledů také území Zalitavska. Příklad profesně vzdělávacích institucí ukazuje na nezbytnost počítat s určitou podregistrací statistických záznamů o odborných školách. Přestože se i v tomto směru situace směrem k první světové válce postupně zlepšovala, zůstala stranou zájmu rakouských statistiků i nadále například soukromá učiliště nedisponující tzv. právem veřejnosti, což se prakticky týkalo zejména dívčích škol. ${ }^{42}$

Ačkoliv je školská statistika zaměřena především na předlitavskou část habsburské monarchie, přinášejí některé svazky Mittheilungen a ÖS porovnání základních dat s jinými evropskými zeměmi (Prusko, Rusko, Švýcarsko, Belgie, Itálie aj.), konkrétně např́iklad ve vybavenosti státi̊ univerzitami a středoškolskými ústavy v přepočtu na rozlohu a obyvatele. Jednotnost zjišt'ovaných rubrik pro celou sledovanou oblast umožňuje provést užitečné srovnání vybavenosti výchovně-vzdělávacími institucemi v jednotlivých částech Předlitavska, $\mathrm{v}$ př́ípadě primárního školství také na regionální (okresní) úrovni.

Zájemce o využití svazků rakouské statistiky školství a vzdělávání by měl mít na zřeteli, že respektují někdejší správní členění. Problém to představuje zejména pro první polovinu 19. století, kdy jsou např́ílad data pro Moravu a Slezsko až do roku 1847 shrnuta do jediného oddílu. Uvedené se týká zejména statistiky primárního školství. U vyšších škol a výchovně-vzdělávacích ústavů sestupovala statistika až na úroveň jednotlivých institucí a organizací, což umožňuje moravské a slezské ústavy rozlišit. Za mírné nedostatky některých starších svazků statistiky (Mittheilungen) lze považovat někdy horší přehlednost a uspořádání dat, které poněkud ztěžují jejich využití. Závažnější slabinou je např́íklad u svazku Mittheilungen pro školní léta 1851-1870 absence číselného údaje o celkovém počtu studentů v jednotlivých zemích. Problematickou je rovněž u Mittheilungen rubrika „národnost“ studentů (východiskem pro ni kritérium mateřského jazyka), která je zde členěna velmi nepřesně a schematicky $\mathrm{v}$ celostátním měřítku na německou, slovanskou (popřr. rozdělenou na jednotlivé větve Slovanů) a na Židy. V př́padě moravských středních

42 P. Kadlec, Vzdělání, s. 44. 
škol jsou zde studenti tř́́děni na: Němce, Čechy a Moravany, Židy. Ve Slezsku rozlišovali statistikové nadto Poláky a Mad’ary. Z hlediska mateřské řeči/národnosti vyvstává problém právě u Židů, kteří jsou považováni za zvláštní „,národ“. U nezřídka bilingvních (mnohdy i multilingvních) moravských a slezských Židů lze přitom předpokládat zejména německou, popř. polskou mateřskou řeč.

Při práci s publikacemi Statistisches Jahrbuch a ÖSH je nutné počítat s tím, že se údaje o oblasti školství a vzdělávání nemusely nutně vztahovat vždy $\mathrm{k}$ roku, jenž byl primárně př́islušným svazkem statistiky sledován. Větší shoda panovala spíše u Statistisches Jahrbuch, kde byly jen ojediněle předloženy údaje pro rok předchozí. U svazků $O ̈ S H$ by měl naopak badatel počítat zpravidla s ročním zpožděním předkládaných statistických dat ke školství a vzdělávání.

Doplňme, že určité nesnáze přináší rovněž vyhledání konkrétních svazků statistických př́ruček. Na území České republiky disponují bohatými, avšak většinou nekompletními řadami jednotlivých statistik knihovny vědecké a dále knihovny větších muzeí a archivů. Vedle mimořádně obsáhlého materiálu uloženého v Národní knihovně v Praze je možné vyzdvihnout např. Vědeckou knihovnu v Olomouci, brněnskou Moravskou zemskou knihovnu nebo knihovnu Národního archivu ČR v Praze. Komplikaci pro badatele představuje nejen roztříštěnost statistik do knižních fondů různých institucí, ale nezřídka i problematické vyhledání. Tyto badateli poměrně málo využívané př́ručky nejsou totiž často zveřejněny v hlavních (elektronických) katalozích, nýbrž pouze $\mathrm{v}$ lístkových katalozích, popř. v jejich naskenované verzi. Kompletní sbírkou statistik se pyšní snad jen Österreichische Nationalbibliothek ve Vídni. Práci s pramenem naopak v posledních letech významně usnadnila postupující digitalizace. Konkrétně lze díky ní studovat statistiky online přes web rakouské národní knihovny (zde kompletní řada TZS a $O ̈ S)^{43}$ a web Austrian Literature Online (kompletní řada Statistisches Jahrbuch). ${ }^{44}$ Některé svazky TZS (např. pro léta 1843, 1844 a 1860-1865), Uebersichts- Tafeln zur Statistik der österreichischen Monarchie (s údaji pro rok 1847) a Statistisches Jahrbuch (např. pro léta 1863-1866, 1870, 1871) jsou ke stažení na internetových stránkách http://books.google.cz. Důležitými zdroji naskenovaných statistických příruček jsou rovněž fondy některých amerických vysokoškolských knihoven (Harvard College Library, University of Michigan aj.).

\section{Závěrem}

Pro rozvoj každé historické disciplíny je důležitá, ne-li zcela klíčová otázka pramenů, at' už ve smyslu rozšiřrení spektra a zpřístupnění zdrojů, nebo vzhledem ke způsobu práce s pramennou základnou. Prakticky to znamená mimo jiné nejen potřebu zapojit prameny nevyužívané zatím bud' vủbec, nebo jen minimálně, ale i změnu př́stupu $\mathrm{k}$ tradičně využívaným zdrojům. V tomto směru nejsou výjimkou ani progresivně se v prostoru českých

43 Srov. <www.onb.ac.at>; všechny svazky TZS na webu Österreichische Nationalbibliothek v rámci Digitaler Lesesaal pod odkazem Austrian Books Online; ÖS dostupné na webových stránkách <alex.onb.ac.at/ors.htm>; ÖS (Neue Folge) na <alex.onb.ac.at/ost.htm> (vše cit. dne 13. 5. 2021).

44 Viz <www.literature.at>; Statistisches Jahrbuch na webu ALO dohledatelný pod odkazem Collections $\rightarrow$ Periodica $\rightarrow$ Sammlung 669 (cit. dne 13. 5. 2021). 
zemí rozvíjející dějiny vzdělanosti. ${ }^{45}$ Bohužel nemáme doposud $\mathrm{k}$ dispozici př́liš mnoho textů, které by představily badatelům uceleně využitelné prameny, poukázaly na možnosti i limity práce s nimi a celkově pomohly zájemcům zorientovat se $\mathrm{v}$ často nepř́liš přehledném spektru zdrojů, včetně jejich nezřídka roztřiššěného uložení. Uvedené samožrejmě neztěžuje práci pouze badatelům realizujícím se na poli dějin vzdělanosti, ale také jejich kolegům reprezentujícím jiné historické disciplíny a subdisciplíny. ${ }^{46}$ Nutno dodat, že takové práce by neplnily pochopitelně „,pouze“ roli vděčných pomocníků již etablovaných badatelů, ale významně by mohly pomoci i těm, jejichž výzkum je teprve v počátcích. Jinými slovy, nejedná se zde jen o zprostředkování jakéhosi „návodu“, ale v obecné rovině o záležitost rovněž spíše motivačního charakteru.

V předkládaném textu jsem se pokusil představit přehledným způsobem a v co možná nejucelenější podobě (vývoj pramene, možnosti a limity využití, uložení) rakouskou statistiku školství a vzdělávání pro léta 1828-1915, bez nároku na úplnost a ve snaze vyjít vstříc výše uvedenému. Mám-li se pokusit o závěrečné shrnutí, pak tento pramen, navzdory některým nesnázím doprovázejícím práci s ním (teprve postupné zpřehlednění rubrik a precizace statistiky, určitá podregistrace školských zařízení, uložení roztříštěné do většího počtu institucí a ne vždy snadné vyhledání konkrétních dokumentů) mohou být velkým př́nosem pro studium (nejen českých) dějin vzdělanosti 19. a počátku 20. století. Pochopitelně záleží na tom, jakým způsobem $\mathrm{k}$ tomuto prameni případní zájemci přistoupí. Posloužit může při studiu celé řady témat jak v šiře definovaném prostoru, tak i při regionálně zaměřeném výzkumu. $\mathrm{V}$ obou př́padech pak obzvláště tehdy, pokud jej doplníme ještě o další zdroje (např. výroční zprávy jednotlivých škol, korespondence na trase školy - stát - nestátní činitelé, katalogy/matriky žáků a studentů, personální spisy učitelů). Hloubka informací předkládaných ve statistikách sice nemírí k úplně detailnímu přehledu, což ale nebylo ani účelem jejich tvůrců. Pramen umožňuje vytvořit především celkovou představu o hlavních vývojových trendech předlitavské vzdělávací infrastruktury (zejména školské, částečně ovšem i mimoškolské), učitelích, žactvu/studentstvu a v př́padech některých typů škol také o jejich materiálním vybavení. Díky množství a struktuře statistických záznamů lze studovat nejen kvantitativní ukazatele, nýbrž i kvalitativní proměnu školské soustavu, a sice jak v rozsahu celopředlitavském, tak v jednotlivých zemích této části habsburské monarchie. Za výhodu pramene lze považovat pokrytí období takřka devadesáti let, což umožňuje sledovat některé jevy v poměrně dlouhém časovém horizontu, ačkoliv ke zpřesnění a rozšíření spektra sledovaných kritérií došlo teprve po polovině 19. století. Rakouská statistika školství a vzdělávání poslouží i komparativně pojatému výzkumu, $\mathrm{v}$ současnosti preferovanému, přičemž srovnání může být vedeno $\mathrm{v}$ rovině geografické (jednotlivé provincie Předlitavska) i tematické (školy určité vzdělávací úrovně, zaměření, vyučovacího jazyka etc.). At’ už se zájemci rozhodnou využít rakouskou školskou statistiku jakýmkoliv způsobem, bude to jedině ku prospěchu dějin vzdělanosti (nejen) českých zemí.

45 K tomu např. P. Kadlec, Studium, s. 58-59.

46 Z cenných,,instruktážních“ prací o pramenech jmenujme kolektivní díla Prameny k hospodářrským a sociálním dějinám novověku, I-II, Ostrava 2008, 2010, nebo Archivni prameny v etnologickém výzkumu, I, Brno 2014, jež představují přehlednou formou souhrnně desítky (nejen) historických pramenů. 


\title{
DIE ÖSTERREICHISCHE SCHUL- UND BILDUNGSSTATISTIK - UNBEACHTETE QUELLEN ZUR GESCHICHTE DER BILDUNG IM „LANGEN“ 19. JAHRHUNDERT
}

\author{
ZUSAMMENFASSUNG
}

Die österreichische Schulstatistik stellt eine wichtige Quelle zur Geschichte der Bildung des sogenannten langen 19. Jahrhunderts im mitteleuropäischen Raum dar, wenngleich dieser von der Forschung bislang relativ unbeachtet blieb und sein Potenzial nur minimal genutzt wurde. Die Studie fußt auf einer größeren Anzahl von Handbüchern, von denen die mit Schlüsselbedeutung (Tafeln zur Statistik der österreichischen Monarchie, Mittheilungen aus dem Gebiete der Statistik, Statistisches Jahrbuch, Österreichisches Statistisches Handbuch für die im Reichsrathe vertretenen Königreiche und Länder, Österreichische Statistik/Neue Folge und spezielle Bände zur Statistik des Grundschulwesens) den Zeitraum von 1828-1915 abdecken. Das Interesse der österreichischen Statistiker konzentrierte sich zwar traditionsgemäß auf den cisleithanischen Raum, doch lassen sich bis fast Ende der achtziger Jahre des 19. Jahrhunderts in den Schulstatistiken solide Informationen auch über den Stand des Schulwesens im transleithanischen Teil der Habsburgermonarchie finden.

Die Entwicklung der österreichischen Schulstatistik reflektiert auf allgemeiner Ebene die Entwicklung der schulischen Infrastruktur, den Fortgang der Institutionalisierung und Professionalisierung bei der Führung der offiziellen österreichischen Statistik, die Präzisierung der Methodik und das Bemühen, die Ergebnisse statistischer Erhebungen der breiten Öffentlichkeit zugänglich zu machen. Sie stand im Zeichen nicht nur eines beträchtlichen quantitativen Zuwachses präsentierter Daten, sondern gleichfalls einer bedeutenden qualitativen Veränderung. Die Statistiken wurden im Laufe der Jahre übersichtlicher, lieferten zuverlässigere Informationen und das Spektrum der statistischen Angaben wurde erweitert und die Angaben selbst vertieft. Die ihrem Inhalt nach ursprünglich nicht allzu umfangreichen tabellarischen Übersichten wandelten sich allmählich zu seitenweise umfassenden und übersichtlich angeordneten statistischen Werken, dank derer man in einem verhältnismäßig langen Zeitraum von nahezu neunzig Jahren eine relativ kompakte Vorstellung von Gestalt und Entwicklung der cisleithanischen Infrastruktur im Bildungswesen gewinnen konnte.

Grenzen, auf die man bei den älteren Statistiken stößt, sind: das begrenzte Spektrum der verfolgten Kriterien, eine schlechtere Übersicht und überhaupt eine problematische Anordnung der Daten bzw. eine nicht allzu bequeme Suche nach konkreten Einzelbänden. Letztere sind in wissenschaftlichen Bibliotheken bzw. in Bibliotheken bedeutenderer Museen und Archiven in der Regel nämlich in zumeist unvollständigen Reihen abgelegt. Die erfreulich vorangehende Digitalisierung der Schulstatistiken und deren Zugänglichmachung in den verschiedensten Webportalen der österreichischen Nationalbibliothek und von Austrian Literature Online wäre zweifellos ein Schritt nach vorn im Sinne einer Erschließung dieser Quelle für einen breiteren Forscherkreis.

(C) Deutsche Übersetzung Wolf B. Oerter

\author{
Mgr. Petr Kadlec, Ph.D. \\ Centrum pro hospodářské a sociální dějiny \\ Filozofická fakulta Ostravské univerzity \\ Petr.Kadlec@osu.cz
}

